若年ドライバの高速道路走行時スマートフォン操作が及ぼす 影響の検証

\author{
荒川 俊也 ${ }^{\mathrm{a}, *}$
}

\title{
Verification the Affect of Using Smartphone of Young Driver on Driving High Way
}

\author{
Toshiya Arakawa,
}

(Received April 12, 2016; revised May 9, 2016; accepted May 18, 2016)

\begin{abstract}
In this paper, the affect of using smartphone by young driver is experimentally verified. Five participants drove the high way with the driving simulator in case of using smartphone and not using smartphone. On the driving, leading vehicle suddenly decelerated and we verify the response time between the time of sudden deceleration and the time of participants' pressing the brake pedal. In addition that, we investigated the data of vehicle, such as velocity, steering angle and brake stroke. As a result, drivers using smartphone on driving tend to be able to control steering but not to control brake pedal well. The time between sudden deceleration and participants' pressing the brake pedal of seemed to be delay more than that of beginners when they use smartphone. From the point of risk feeling, the drivers who get used to driving feel risk when they use smartphone on driving more than beginners.
\end{abstract}

キーワード : スマートフォン操作, 運転, リスク, リスクフィーリング

Keywords : Operating smartphone, driving, risk, risk feeling.

\section{1.はじめに}

本論は，若者のドライバを対象として，高速道路走行 時におけるスマートフォン操作による影響について実験 的に検証したものである。

スマートフォンは近年一家に一台普及していると言わ れている程便利なデバイスである。しかし，それに伴う 事故も増えつつある。その事故の一つが自動車の運転中 にドライバがスマートフォン操作を行うことによる人身 事故または衝突事故である。特にアメリカでは重大な社 会問題に発展しつつあり, 米運輸省高速道路交通安全局 (NHTSA)の報告によると，運転中のスマートフォン操作 が原因で 2012 年に 3,328 人が死亡しているとされてい る(1)。2010 年においても 3,000 人以上が死亡し，40 万 人以上が怪我をしていると言われている(1)。20 代から 50 代までの 1000 人を対象とした三井ダイレクト損保リサ

\footnotetext{
* Corresponding author. E-mail: arakawa-toshiya@aut.ac.jp

$\mathrm{a}$ 愛知工科大学

干443-0047 愛知県蒲郡市西迫町馬乗 50-2

Aichi University of Technology

50-2, Manori, Nishihasama-cho, Gamagori, Aichi, Japan 443-0047
}

ーチのアンケートによると,「運転中にスマートフォン操 作をしたことがありますか?」という質問を週に一回以 上運転する 20～30 代の男性 200 人にアンケートを行っ た結果,約 8 割のドライバが運転中にスマートフォン操 作したことがあると回答した ${ }^{(2)}$ 。また，20 代から50 代 の $57.7 \%$ 割合で「運転中にスマートフォンが気になる」 と回答している。同アンケートでは，20 代の $65.1 \%$ ， 「運転中にスマートフォンが気になる」と回答しており， 若年者ほど運転中にスマートフォンが気になっていると 指摘している。さらに，「運転中にスマートフォンが気に なる」と回答したドライバの約 5 割のドライバがヒヤ リ・ハットの経験があると回答している(2)。高速道路に おけるスマートフォン操作については，大手旅行会社が 主催するツアーで, 男性運転手がスマートフォンを操作 しながら走行するという問題も発覚した(3)こともあり， 運転中のスマートフォン操作は社会的な問題となってい るのが現状である。

以上のことからドライバ，特に若者が運転中にスマー トフォン操作を行うことに対する危険意識の低下が疑わ れる。そのため, 今後の事故数の増加,問題の深刻化を防 
ぐためにも運転中のスマートフォン操作の危険性を改め てドライバに伝え危険意識を高める必要性がある。運転 中の携帯電話などのモバイル端末による通話が運転に及 ぼす影響については先行事例が多くあるが(4-7), 運転中の スマートフォン操作については, 様々なメディアにおい て追求されているものの, その危険性について定量的に 評価を行っている例は極めて少ない。特にスマートフォ ンは, 従来の携帯電話と異なり, 多様なコンテンツを楽 しむことが可能であるため，スマートフォンを見ながら 歩く「ながらスマホ」や, 先の運転中のスマートフォン 操作のような危険行為を誘発する原因となる。そこで, 本研究では, 比較的単調な走行環境である高速道路にお いて, 運転中にスマートフォン操作の行った時の危険性 の検証を目的とした実験を行う。そして，スマートフォ ン操作の有無によって, 先行車の急減速に対する認知お よびブレーキペダルを踏むという判断の遅れが生じるか 否か, リスクの意識が変化するかを検証する。

本論の構成は次の通りである。第 2 章では実験内容に ついて説明する。第 3 章では実験結果について述べる。 第 4 章では実験結果を基にして, 認知判断および車両挙 動の観点からスマートフォン操作有無における危険性に ついて述べる。第 5 章はまとめである。

\section{2. 実験}

若者を対象とし, 実験は男子大学生 5 名(平均年齢 23.4 歳, 以下実験協力者 $\mathrm{A} \sim \mathrm{E}$ と称す)について実施した。実 験協力者は全員自動車免許保有者である。実験はドライ ビングシミュレータ (D3sim, 三菱プレシジョン製)におい て, 走行車線と追越車線の 2 車線から構成される, 見通 しの良いなだらかなカーブがある高速道路を走行して実 施した。

それぞれの実験協力者は車速 $100 \mathrm{~km} / \mathrm{h}$ を維持して走 行するように教示された。自車両の前方に約 $100 \mathrm{~m}$ の間 隔を常に維持するように先行車が走行しており，実験協 力者は, 先行車に追従走行するように指示された。先行 車が 3 回急減速し, 自車がブレーキを踏下し減速, 完全 停車した所で実験が終了寸る。なお，先行車が急減速す るタイミングはランダムであるが，急減速してすぐに再 度急減速しないように設定した。実験協力者には先行車 が急減速すること，および，急減速するタイミングは一 切伝えていない。走行中, 自車両から見た様子を図 1 に 示す。

この走行実験を 2 回実施した。1 回はスマートフォン を操作せずに走行, もう 1 回はスマートフォン (iphone 4, アップル株式会社製)を操作して走行した。なお，スマー トフォン操作は, 概衩ステアリングの横の位置で把持し て片手操作をするように教示した。ただし，操作位置は 固定せず，ほぼステアリングと同じ高さで，自然な操作

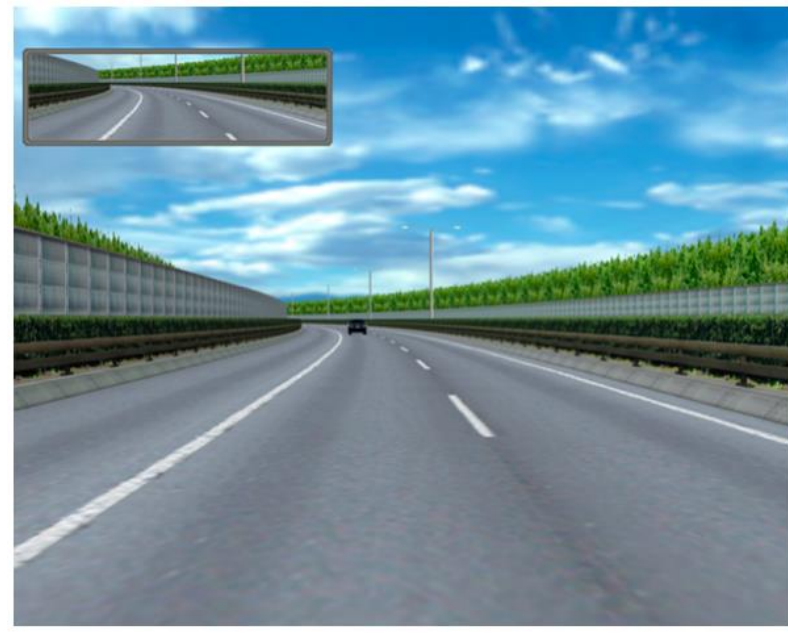

Fig. 1. Scene from driver's view.

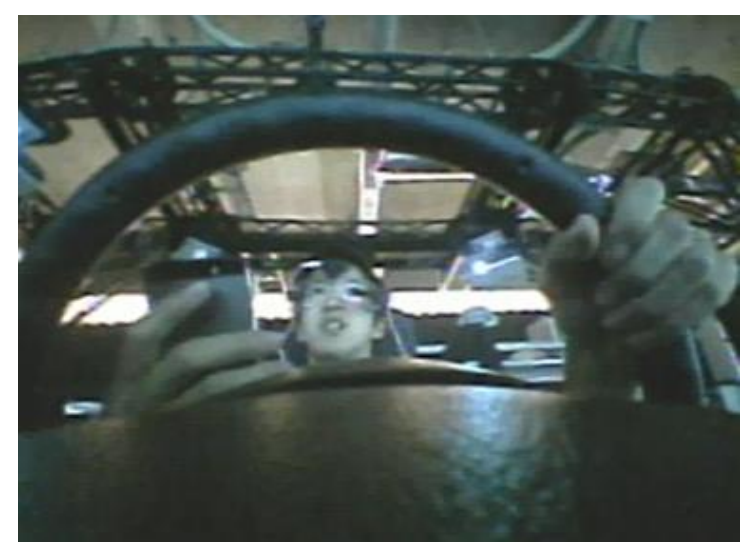

Fig. 2. Driver's expression on driving.

ができる位置で操作をするように教示した。

スマートフォン操作は, iOS 用アプリケーションソフ 卜「暗算トレーニング計算で脳トレ!」を用いて実施し た。これは, スマートフォン画面上に表示される 1 桁+1 桁の計算問題をひたすら解かせるアプリケーションソフ トであり, 計算結果に該当する数値を入力し, 決定キー を押すことで計算結果を回答するものである。実際の運 転時のスマートフォン操作は, メール, LINE, twitter 入 力, ゲーム操作などが考えられるが，操作の複雑さは目 的により異なる。メール入力や twitter 入力については文 章の構成や長短によっても異なる。そのため, メール入 力や twitter 入力をタスクとして与えた場合, タスク毎の 難易度のバラつきが大きくなることが懸念される。そこ で，バラつきを抑える目的で，比較的単純な計算問題の 回答をタスクとして設定した。また，本論における検証 では使用しないが，参考までに，実験協力者にはアイマ ークレコーダ(TalkEye Lite，竹井機器工業株式会社製)を 装着させ, 視線挙動も計測した。実験時の実験協力者の 様子を図 2 に示す。なお, 本実験は, 実験協力者のイン フォームドコンセントを得て実施した。 


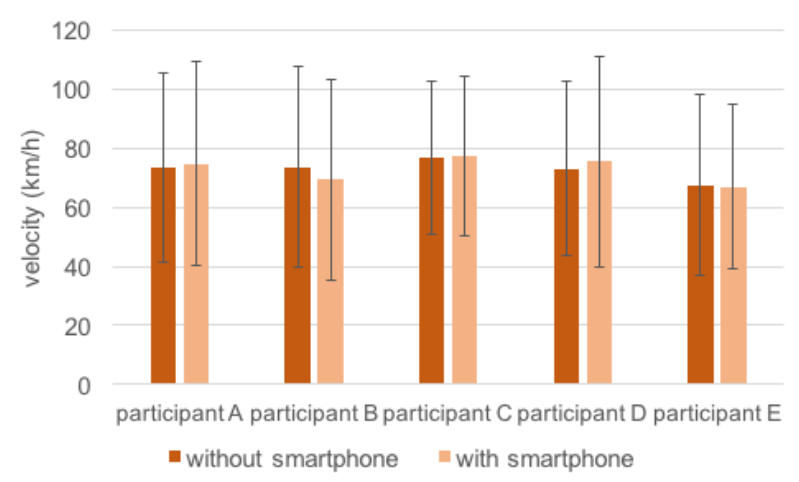

Fig. 3. Velocity on driving without/with smartphone.

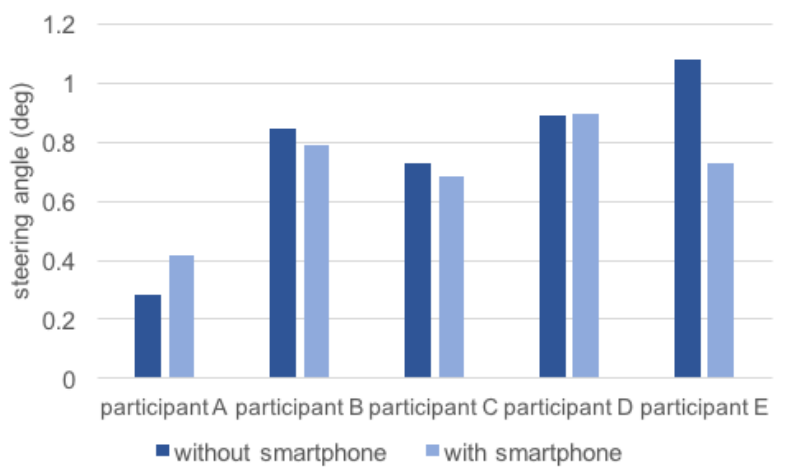

Fig. 4. Degree of steering angle on driving without/with smartphone.

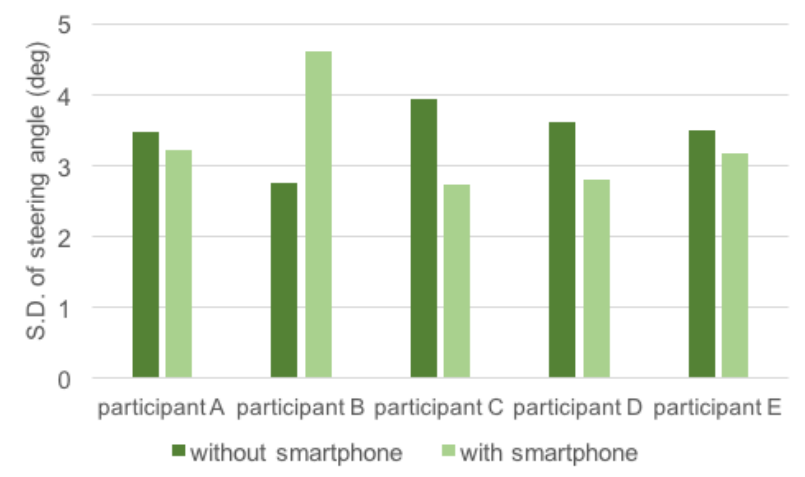

Fig. 5. S.D. of steering angle on driving without/with smartphone.

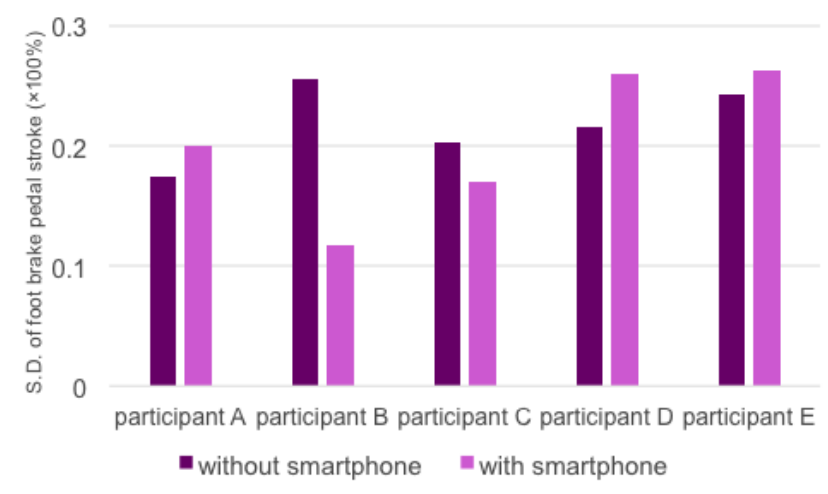

Fig. 6. S.D. of foot brake stroke on driving without/with smartphone.

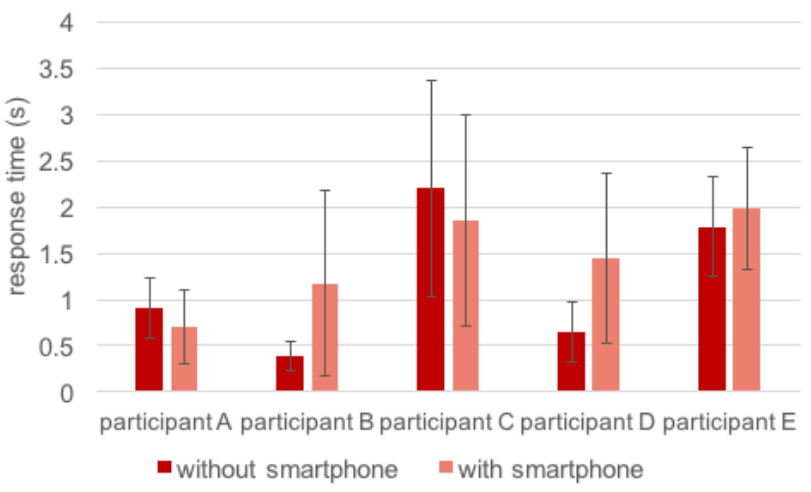

Fig. 7. Response time of each participant when proceeding vehicle suddenly decelerates.

Table 1. Response time of each participant when proceeding vehicle suddenly decelerates.

\begin{tabular}{|c|c|c|}
\hline & $\begin{array}{c}\text { without } \\
\text { smartphone }\end{array}$ & $\begin{array}{c}\text { with } \\
\text { smartphone }\end{array}$ \\
\hline participant A & $0.91 \pm 0.33$ & $0.70 \pm 0.40$ \\
\hline participant B & $0.38 \pm 0.16$ & $1.18 \pm 1.00$ \\
\hline participant C & $2.20 \pm 1.17$ & $1.86 \pm 1.15$ \\
\hline participant D & $0.65 \pm 0.33$ & $1.44 \pm 0.92$ \\
\hline participant E & $1.79 \pm 0.54$ & $1.98 \pm 0.66$ \\
\hline
\end{tabular}

Note: Data are mean \pm 1 S.D. unit: $s$

\section{3. 実験結果}

\section{1 運転中のドライバ行動}

走行開始から終了までの車速, ステアリング角度の值と, それぞれの標準偏差およびブレーキペダルストロークの 標準偏差を図 3 から図 6 に示す。なお, 図 3 は車速と標 準偏差を共に示している。図 4 はステアリング角度の值, 図 5 はステアリング角度の標準偏差を示している。なお, 図 4 において, ステアリング角度の正值は右方向への転 舵を意味する。

3.2 先行車急減速時における反応について

スマートフォン操作の有無毎に, 先行車が急減速して から実験協力者がブレーキを踏み始めるまでの時間につ いて計測した。急減速については定義が様々であるが, 本論では $0.3 \mathrm{G}$ 以上の減速度が生じた場合 ${ }^{(8)}$ を急減速と 定義した。全ての実験協力者に関して，3回の急減速に おける時間の平均と標準偏差を, 図 7 おび表 1 に示す。

3.3 ドライバが感じるリスクについて

スマートフォン操作の有無について, ドライバが感じ るリスクについて算出した。まず, 衝突余裕時間(TTC: Time To Collision)および車間時間(THW: Time HeadWay) は次のように定義される。

$$
\mathrm{TTC}=\frac{L_{r e l}}{v_{\text {rel }}}
$$




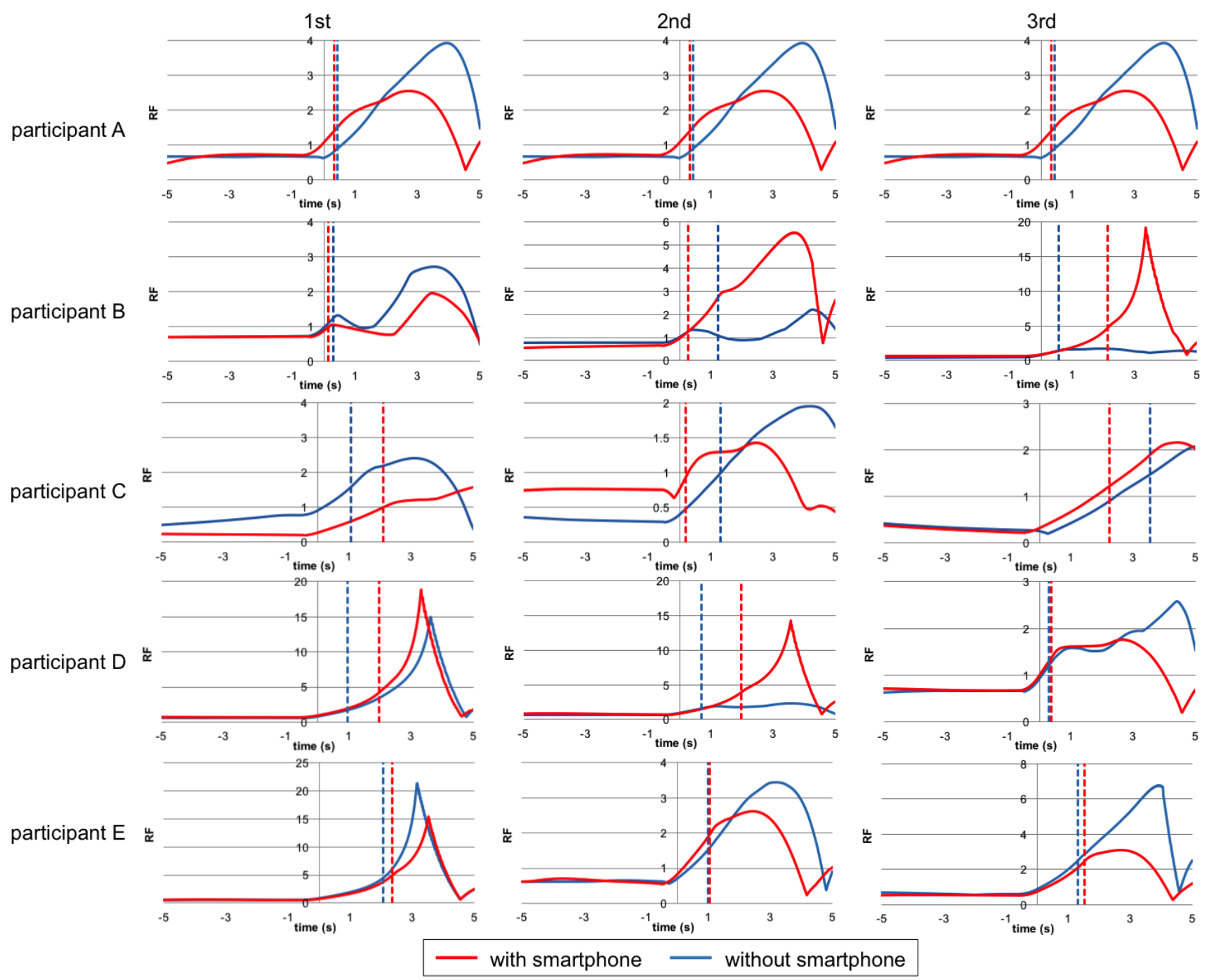

Fig. 8. The time-series graph of RF(risk feeling) of each participants.

$$
\mathrm{THW}=\frac{L_{r e l}}{v_{o w n}}
$$

但し， $L_{r e l}[\mathrm{~m}]$ は先行車と自車両の相対距離， $v_{r e l}[\mathrm{~m} / \mathrm{s}]$ は 先行車と自車両の相対速度， $v_{\text {own }}[\mathrm{m} / \mathrm{s}]$ は自車両の車速で ある。

式(1)および式(2)の TTC と THW を基にして, リスクフ イーリング指標(RF: Risk Feeling),

$$
\mathrm{RF}=\frac{a}{\mathrm{THW}}+\frac{b}{\mathrm{TTC}}
$$

を計算する。ここで， $a$ と $b$ は, THW の逆数である iTHW(inverse THW)が示す定数項と, TTCの逆数である iTTC(inverse TTC)が示す過渡項のそれぞれの重みを示す ものである。ドライビングシミュレータにおける実験結 果に最もフィットする值として $, a=1, b=5$ という結果が 得られている(9)ため, 本論でも $a=1, b=5$ として計算した。 5 名の実験協力者について, 先行車の 1 回目の急減速か ら 3 回目の急減速における RF の変化を図 8 に示す。な お, 図 8 は, 急減速開始(減速度が $0.3 \mathrm{G}$ となったタイミ
ング)から先行車の減速度が初めて最大值になった時間 を基準として, その前後 $5 \mathrm{~s}$ の RF の時系列変化を示して いる。なお，スマートフォン操作が無い場合の運転時の $\mathrm{RF}$ の時系列変化は青線で, スマートフォン操作がある場 合の運転時の RF の時系列変化は赤線で示している。ま た，先行車の減速に気付いてブレーキペダルを踏下した タイミングについては，スマートフォン操作が無い場合 の運転時は青破線で，スマートフォン操作がある場合の 運転時は赤破線で示している。

\section{4. 考察}

\section{1 運転中のドライバ行動について}

図 3 より，スマートフォン操作による車速の変化と標 準偏差，および，ステアリング角の変化について，顕著 な傾向は見られない。しかし, 図 4 より, スマートフォ ン操作がある場合は，スマートフォン操作が無い場合に 比べて，ステアリング角が抑えられている，つまり，0 $\operatorname{deg}$ (中立)に近い角度になっている傾向がある。また, 図 
5 より，実験協力者 B 以外は，全て，スマートフォン操 作が無い場合に比べて，スマートフォン操作がある場合 の運転の方が，ステアリング角の標準偏差の值が小さい ことがわかる。すなわち, スマートフォン操作時は, ド ライバは左右方向の制御については慎重に行っている可 能性が示唆される。

次に, 図 6 より, ブレーキペダルストロークの標準偏 差について考察する。ブレーキペダルストロークの標準 偏差が大きいということは, 自車両が急減速する傾向に あることを意味する。これを踏まえて, 図 6 より，実験 協力者 $\mathrm{A}, \mathrm{D}, \mathrm{E}$ の 3 名は, スマートフォン操作時の方 がブレーキペダルストロークの標準偏差が大きいことか ら, 先行車の急減速に併せて, 自車も咄嗟に急減速する 傾向にあると示唆される。

以上より，スマートフォン操作時は，ドライバは操舵 に伴う左右方向の制御に対しては, 車線逸脱しないよう に注意するという意識が働くことに起因して，慎重に操 作を行っていると考えられる。スマートフォンをステア リング近傍で操作していることにより， ステアリングが 操作しやすい環境にあることも影響していると考えられ る.しかし, 前後方向については車速制御が上手く行え ず，そのため，ブレーキペダルストロークの変化が大き くなるために標準偏差も大きくなると考えられる。これ は, スマートフォン操作による画面確認や注視に起因し て，先行車に対する注意配分が減少することによると考 えられる。

\section{2 先行車急減速時における反応について}

図 7 と表 1 より, 実験協力者 B, D, E について, スマ 一トフォン操作がある場合の方が，スマートフォン操作 が無い場合に比べて反応時間が遅れる傾向が見られる。 特に, 実験協力者 B および D については, 走行状態から 車両を停止させる場合の反射時間(知覚判断してから行 動に現れるまでの時間), 踏み変え時間, 踏み込み時間を 合計した「ブレーキ反応時間」と言われる約 $0.6 \mathrm{~s}^{(10)}$ (約 $17 \mathrm{~m}$ の空走距離に相当する）以上と顕著に反応時間が遅

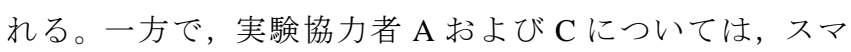
一トフォン操作の有無に拘らず, 反応時間に違いが見ら れない。実験協力者 $\mathrm{A}, \mathrm{C}, \mathrm{E}$ について共通する傾向とし て, 免許を所有しているものの, ペーパードライバであ るため, 殆どクルマを運転しないという傾向がある。こ れらの実験協力者は, スマートフォンを操作するように 教示されても, 運転に集中しなければならないという意 識が強く働いていたため, 先行車の方向に意識が向いて いた。そのため, 先行車が急減速しても, ブレーキペダ ル踏下する時間が，スマートフォン操作が無い時と殆ど 変わらない結果になったと考えられる。実際, これらの 実験協力者は,「ドライビングシミュレータの運転である が, 先行車にぶつからないようにしなければならないた
め，スマートフォンを操作することよりも，前をかなり 気にしていた」という事後報告があった。

4.3 ドライバが感じるリスクについて

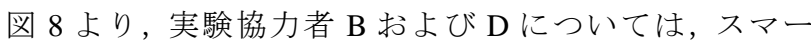
トフォン操作時の方が，スマートフォン操作が無い場合 に比べて, RFの值が大きい傾向にある。しかし，その他 の実験協力者については，スマートフォン操作が無い場 合の方が，RFの值が大きい傾向にある。言い換えると， スマートフォン操作時の方が, スマートフォン操作が無 い場合に比べると, リスクの意識が低いことが示唆され

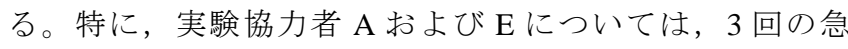
減速全てについて同じ傾向が見られる。4.2 で述べたよ うに, 実験協力者 $\mathrm{A}, \mathrm{C}, \mathrm{E}$ について共通する傾向として, 免許を所有しているものの, ペーパードライバであるた め, 殆どクルマを運転しないという傾向がある。しかし, スマートフォンを操作しながらであっても，前方に十分 注意をしていたため, 急減速におけるリスクの意識は, スマートフォン使用の有無に拘らず, さほど変化が無い と考えられる。一方で, 実験協力者 B, D については, 運転頻度が他の 3 名の実験協力者に比べて多く，運転に 慣れているため，スマートフォン操作に集中しており， 前方に注意を払っていなかった。そのため, 先行車の急 減速に伴い, 咄嗟の判断を要することも起因し，リスク の意識が他の実験協力者に比べ高くなったと考えられる。

\section{5.まとめ}

本論では，運転中のスマートフォンが気になるという 割合が多い若年ドライバに対し，ドライビングシミュレ ータによる高速道路走行実験を実施することで, 運転時 のスマートフォン操作による影響を検証した。その結果, スマートフォン操作時はステアリング操作に対して慎重 になっている一方で, ブレーキ操作については, スマー トフォン操作による画面確認や注視に起因して, 先行車 に対する注意配分が減少するため，車速制御が上手く行 えず，そのため，ブレーキペダルストロークの変化が大 きくなる傾向が見られる。先行車の急減速に対するブレ 一キ踏下時間については，運転頻度が少ないドライバに ついては，運転の慎重さに起因して，スマートフォン操 作の有無で差が見られないが，運転頻度の多いドライバ については，スマートフォン操作がある場合，スマート フォン操作に意識を向けているため, 急減速時のブレー キ踏下時間が遅くなる傾向にある。最後に, リスクフィ ーリング指標の観点から，ドライバのリスク感受性につ いて検討した所, 運転頻度が少ないドライバに比べて, 運転頻度が多いドライバの方が急減速時のリスク感受性 が高い傾向にあることがわかった。これらのことから， 運転に慣れたドライバが，スマートフォンを操作しなが ら運転をすると，慣れに伴う油断によるかは今後検証の 
必要があるが，走行環境に対する注意を払わないことに 起因し, 認知判断遅れやリスク意識の増加も示唆された。

但し, 本論は若年男性ドライバを対象とした実験であ り, 今後は女性ドライバおよび中・高年齢層のドライバ に対しても検証を行う必要がある。男性に比べて女性の 方が単純反応時間の遅れが見られるという結果があるこ と $^{(10)}$, ブレーキランプに対する反応は年齢層による差が 認められないこと ${ }^{(11)}$, タッチパネル操作については, 男 性より女性の方が短いこと, また, 中・高年齢層の操作 時間は，青年層や子供らの年齢層との間で有意差が認め られること ${ }^{(12)}$ な゙から, 特に高齢者について運転中のス マートフォンの影響が大きいことが考えられる。これら の先行研究の結果が手がかりになると考えられるが，い ずれにせよ，女性ドライバおよび中・高年齢層のドライ バに対する検証は今後の課題である。

本論で述べたことは至極当然の話であると感じる読者 も多いかも知れない。しかし, 本論のように定量的に示 し, また, リスクフィーリングの観点からも論じること によって，運転中のスマートフォン操作が，特に運転頻 度の多いドライバにとって危険な行為であることを改め て理解することに繋げる必要があり，本論はそのような 観点から資料的価值があるものと考える。例えば，運転 経験のあるドライバに対して特に啓蒙する観点から，運 転免許更新時の講習などの場で,「運転に慣れたドライバ ほど，気の緩みから，運転中にスマートフォンを使って しまう傾向にある。しかし，スマートフォンを使用して 高速道路を運転した場合, 先行車の急減速に対する反応 が遅れ， $17 \mathrm{~m}$ 以上余計に走行してしまう。その分，追突 のリスクが高まる。」いうことを本論のデータをべース に伝える，などの方法があると思われる，加えて，運転 時のスマートフォン操作を防止するアプリケーション開 発などの産業応用に繋がることにも期待したい。

\section{謝辞}

本研究は多治見謙成氏(前: 愛知工科大学工学部機械シ ステム工学科学生, 現: シーシーアイ株式会社)の協力の 下行われた。ここに感謝の意を表する。

\section{文献}

（1）情報通信総合研究所 InfoCom ニューズレター：「アメリカとチリ の「運転中スマホ」での事故防止にむけた注意哃起ビデオ」, http://www.icr.co.jp/newsletter/global_perspective/2014/Gpre2014082. $h t m l($ 最終アクセス日：2016 年 4 月 11 日)

(2) 三井ダイレクト損保リサーチ:「スマホとドライブに関するアンケ ート調查〜スマホとドライブの関係を調査！三井ダイレクト損保 がリサーチ〜」,

http://news.mitsui-direct.co.jp/topics/20150810/index.html?id=40204
(最終アクセス日: 2016 年 4 月 10 日)

(3) 産経ニュース,「ッアーバス運転手が高速運転中にスマホ操作「渋 滞情報見るため」」，

http://www.sankei.com/affairs/news/160323/afr1603230045-n1.html (最終アクセス日: 2016 年 4 月 10 日)

(4) David L. Strayer, William A. Johnston: "DRIVEN TO DISTRACTION: Dual-Task Studies of Simulated Driving and Conversing on a Cellular Telephone”, PSYCHOLOGICAL SCIENCE, Vol.12, No.6, 2001, pp462-466

(5) David L. Strayer, Frank A. Drews, William A. Johnston: "Cell phone induced perceptual during simulated driving”, International Symposium on Human Factors in Driver Assessment, 2001

(6) Oron-Gilad, T., Ronen, A., Shinarm, D.: "Alertness maintain tasks (AMTs) while driving”, Accident Analysis and Prevention, Vol.40, No.3, 2008, pp851-860

（7）高野暁秀, 今関みさと, 西口宏美, 辛島光彦:「会話が視覚情報認 知に与える影響一自動車運転中のハンズフリー使用を想定した検 討一」, 東海大学紀要情報通信学部, vol.7, No2, pp.37-43, 2014

(8) 国土交通省：「交通事故削減のための更なる効率的・効果的な取り 組み」, 国土交通省 道路分科会 第 40 回基本政策部会 議事, 2012

(9) T. Kondoh et al.: "Identification of Visual Cues and Quantification of Drivers' Perception of Proximity Risk to the Lead Vehicle in Car-Following Situations", Journal of Mechanical Systems for Transportation and Logistics, Vol.1, No.2, pp.170-180, 2008

(10) 最高速度違反による交通事故対策検討会:「自動車の走行速度の低 下による交通事故の低減効果等」,

http://www8.cao.go.jp/koutu/taisaku/max-speed/k_3/pdf/s5.pdf( 最 終 アクセス日：2016 年 4 月 12 日)

(11) 野原弘嗣：男女別，年齢階級別の単純および跳躍反応時間（17〜 59 歳の勤労者についての観察），体力科学, 31, 1982, pp28-40

(12) 牧下寛, 松永勝也：自動車運転中の突然の危険に対する制動反応 の時間，人間工学, Vol.38, No.6, 2002,pp.324-332

(13) 岸田孝弥, 自動接客機器の人間工学的研究,

http://www.kenf.jp/annualreview/2000/kr_004.html（最終アクセス 日：2016 年 5 月 9 日)

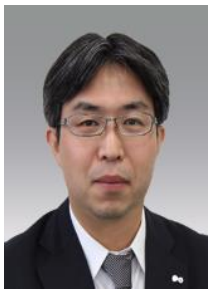

荒川俊也

2001 年 3 月早稲田大学理工学部機械工学科卒 業, 2003 年 3 月東京大学大学院総合文化研究科広 域科学専攻博士前期課程修了。同年 4 月富士重工 業株式会社スバル技術研究所に勤務, その間 2012 年 9 月総合研究大学院大学複合科学研究科統計科 学専攻博士後期課程修了。政策研究大学院大学を 経て，2013 年 4 月愛知工科大学准教授，2016 年 4 月より愛知工科大学教授，現在に至る。人間-機械 系研究(特に自動運転時のヒューマンファクタ), HMI 設計，機械学習による大型動物の行動推定, 電力供給量の統計モデリングなどの研究に従事。 